УДК $811.111^{\prime} 37+81$ '367.623

DOI: $10.24144 / 2617-3921.2020 .18 .9-17$

Myroslava Fabian

Doctor of Philology, Professor, Professor of English Philology Department

Uzhhorod National University orcid.org/0000-0002-3351-1275

Uzhhorod, Ukraine, +38(066)2906929 myroslava.fabian@uzhnu.edu.ua

\title{
Linguocultural approach to the study of lexical semantics
}

Анотачія. Сучасне мовознавство характеризується посиленим інтересом до досліджень лексичної семантики. В иььму контексті особливої ваги набуває всебічний аналіз системно-структурної організачії вокабуляра сучасної англійської мови. В період глобалізації найвідчутніші зміни в житті людини, ї̈ побуті, суспільній діяльності і т.n. спостерігаються й знаходять своє відображення у словниковому складі мови, особливо в лексиці. Остання володіє иілим арсеналом мовних засобів для передачі, відтворення, навіть зміни існуючих та фіксачії нових слів разом з їхніми значеннями. Як $і$ будь-яка інша мова, англійська має свою неповторну систему й структуру, а також елементи, які розташовуються ієрархічно в ї̈ семантичному просторі. Роль $i$ місие слів у системі набувають визначального значення та сприяють встановленню різноманітних взаємозв'язків як між собою, так $i$ з іншими елементами в межах досліджуваної мови. Комплексний аналіз лексикосемантичних особливостей слів дозволяє глибше пізнати й найсуттєвіші риси відповідних національних мовних культур. Саме лінгвокультурологічному підходу до вивчення семантики прикметників присвячена ия стаття. Джерелами збору, аналізу й класифікачіï мовного матеріалу слугували лексикографічні джерела сучасної англійської мови. Остання найповніше представлена в словниках, які, будучи об'єктом лінгвістичної діяльності, одночасно виступають ї̈ інструментом і засобом виконання дослідницьких та практичних завдань. На матеріалі моносемічних прикметників, що позначають властивість бути щасливим, розкрито тісний взаємозв'язок мови та культури, особливостей його прояву та відображення відповідними мовними засобами. Проаналізовано 19 моносемічних прикметників, виділено їхні спільні й відмінні риси, виділено особливості їхньої семантики, а також шляхи вербалізації досліджуваного фрагмента емотивної лексики в сучасній англійській мові. На основі проведеного дослідження описано й визначено семантичну цे комунікативну сутність здатності бути щзасливим (щасливою), ї̈ специфіку прояву та особливості функціонування в досліджуваній мовній системі. 
Ключові слова: лексична семантика, вокабуляр мови, культура, система $i$ структура, семантичний простір, словник, спільні й відмінні риси, моносемічні прикметники, лінгвокультурологічний підхід.

Abstract. Contemporary linguistics is characterized by the growing interest in the study of lexical semantics. In this respect of primary importance is the indepth analysis of the system and structural organization of modern English vocabulary. In the globalization period the most perceptible changes in the life of a person, his/her everyday and social activities etc. take place in the language's vocabulary, i.e. lexis. The latter possesses a variety of verbal means to transfer, reveal, and even alter the existing ones, replacing them by the newly created words together with their meanings. Like any other language, English has its unique system and structure, and also elements, which are hierarchically placed in its semantic space. Both role and place of words are of great significance, and help establish various relationships between the words belonging to a definite group as well as other elements within the language system under research. Complex analysis of lexico-semantic specificity of words makes it possible to deeper study the most essential features of corresponding national cultures. The present paper deals with linguocultural approach to the study of lexical semantics. Lexicographical sources of modern English serve as a means of collecting, analyzing and classifying the obtained language material. English is best and to the fullest extent represented in the dictionaries, especially explanatory ones. On the material of monosemantic adjectives denoting the property of being happy, close links between language and culture, peculiarities of their expressions as well as their verbalization means have been revealed. 19 monosemantic adjectives have been studied, their common and distinctive features determined, their semantic specificity and ways of emotive lexis, fragment verbalization revealed. On the basis of the conducted research, both semantic and communicative essence of being happy, its expression and functioning peculiarities in English have been determined and described.

Keywords: lexical semantics, language vocabulary, culture, system and structure, semantic space, dictionary, common and distinctive features, monosemantic adjectives, linguocultural approach.

Introduction. Contemporary linguistics is characterized by the growing interest in studying the language as a socio-cultural phenomenon of anthropocentric nature with a focus on a person and his/her role in organization and usage of language as a means of communication. Emotions are connected with human needs that lie in their motives and activity. They occupy an extremely significant place in human life, accompanying any activity and performing communicative, cognitive and regulatory functions. In this respect the problems of emotive semantics are closely connected with emotional aspect of human factor in language and are relevant in modern linguistics. Attaching words to feelings and emotions is one of the most important aspects of the language, cognition and society interaction. Experiencing positive 
emotions like happiness, excitement, joy, hope, and inspiration is vital for anyone who wants to lead a happy and joyous life. The fundamentals of the English language use are interwined with social and cultural concerns. English nation adjusts its language so as to make it appropriate in various situations in terms of social relationship. Both the meanings of the words and culture unite collective, nationallybiased beliefs and individual experience gained in socio-cultural environment. Happiness is such a central concept in life that not many people pause to consider what happiness is and why we strive so tirelessly to attain it. The power of positive thinking comes in different forms, but they are all helpful. Modifying nouns, English adjectives denoting the property of being happy give additional emotional character, thus specifying the notion of happiness. Semantics of such lexical units has a clearly anthropocentric character, i.e. regarding human existence as the most important and central fact in the world.

Language is much more than the external expression and communication of internal thoughts formulated independently of their verbalization. It is transmitted culturally, i.e. it is learned. Language is viewed as an "entity" where culture lives and develops. It serves, but does not define culture, being the socialized part of the latter. Together they constitute a special unity, a complex multidimensional system whose segments constantly interact with each other. The common features of language and culture lie in the fact that culture as well as language is a form of consciousness that reflects a person's worldview. Language is the most valuable source of national mentality manifestation and the main means that contributes to culture preservation. It reflects not only the real world surrounding a human being, his/her living conditions, but also people's social consciousness, national character, lifestyle, traditions, customs, system of values preserved in certain images and knowledge verbalized by language.

Significantly, the relationship between language and culture is deeply rooted. Language is used to maintain and convey culture and cultural ties. The understanding of a culture and its people can be enhanced by the knowledge of their language. Furthermore, one cannot understand his/her culture without accessing its language directly. It is possible to explore the culture of a certain nation through its language.

The concept of "culture", as well as other socio-humanitarian categories, has been formed gradually, along with the development of human society. In a broad sense, culture is everything that is created by a human being and opposed to what is created by nature. O. Selivanova defines culture as "a complex phenomenon of life characteristic of a certain group, ethnic group or civilization, which preserves symbolic ways of material and spiritual awareness of the world in their collective memory, models of its knowledge and interpretation, as well as ways of collective existence by representatives of different nations, one ethnic group or a certain group" [1, p. 277]. Culture is "the customs, beliefs, art, music, and all the other products of human thought made by a particular group of people at a particular time" [6, p. 311]. 
A clear distinction is usually made between material (tools, household items, clothing, vehicles, etc.) and spiritual culture (cognition, morality, education, etc.). These two types of culture are inseparable, dialectically connected and consistent. Material phenomena, on the one hand, are the basis of the spiritual, and, on the other, the spirituality of culture is largely realized in the material sphere: there is a direct connection between them.

The complexity of emotional semantics research is caused by a complicated nature of emotional concepts, their nomination processes as well as their description and expression in English. To reveal a particular emotion in similar situations, different language means are used. Besides, to actualize different emotions one and the same language units and mechanisms can be used. Moreover, there are emotions that cannot be expressed verbally, and are revealed nonverbally through prosody, tone of voice, facial expressions, gestures, eye contact etc. The individual's ability to control the verbal expression of emotions, to bring them through situational, social and other conscious processes points to the intelligence of communicative emotivity. Semantic properties of the lexis are not only restricted to description of denotative potential, but lie in the expression of emotional attitude to the subject and communicative situation. The bulk of lexical means made up of a set of words with emotional semantics is called emotive vocabulary. It includes words which do not explicitly express emotions, but nominate them. V. I. Shakhovsky classifies emotions owing to their distribution between the following groups of lexis: 1) the words denoting emotions; 2) the words describing emotions; and 3) the words expressing emotions [2, p. 92]. The communicative function of these linguistic means lies in the demonstration of various emotions verbally. Common and distinctive features of the words' semantics research affect the multifunctionality of emotional lexis and creates difficulties for its comprehension and usage.

Each linguoculture interprets emotions in its unique way, attaching social and pragmatic connotations to the words nominating them. Culture to a great extent influences the systems of social beliefs, social organization and semantic presentation of language elements having to do with emotions in each particular language. Positive emotion is the exprerience formed on the basis of favourable impressions, happy events and situations, expectations and hopes. The unity of these notions provides a basis for human consciousness.

Emotional vocabulary functions and develops in close connection with society. In human consciousness the knowledge of the world and cognitive experience are realized in the words' lexical meanings. A human being as a bearer of consciousness plays an important role in the formation and storing the meanings of the language units. The national culture and history are closely connected with language means, reflecting the general worldviews, attitudes towards people, objects, things, etc. and their relations with them. Happiness is viewed as the emotional state that requires being active, energetic, confident in oneself, friendly with others, satisfied with life, proud of what has been attained and always hopeful that something good will happen. It is a deep and positive emotion, that makes the 
perceptual system stonger and optimizes all psychic processes, creating the feeling of confidence, satisfaction, pleasure, joy, liveliness etc.

Material and methods. The methods of linguocultural research include a collection of language material, its description, classification and study as well as formalized analysis of monosemantic adjectives' lexical semantics [3;4]. Besides, the continuous sampling analysis of the language material from lexicographical sources, the analysis of dictionary definitions and the descriptive method have also been used.

Firstly, the analysis of lexicographical sources has been applied. It allowed to select thoroughly the adjectives represented by definitions with the indication of the property of being happy in the English language. Language as a system is most fully represented in dictionaries. Since extralinguistic phenomena are reflected in the language, it is advisable to use lexicographical sources to identify the components of a particular lexical semantic grouping of words. Secondly, to analyze our language material, we turned to the explanatory dictionary of contemporary English, because it reflects the meanings of the words used to verbalize concepts relevant to a particular society. Explanatory dictionaries are the most complete sources of information and fixation of language units. They allow to carry out the in-depth study of all the adjectives denoting the property of being happy in English [5;7]. Our linguocultural approach to the research of lexical semantics combined with the abovementioned methods and procedures of analysis has shown that in modern English 38 lexical units are used to reveal the emotional properties of being happy. Moreover, they form a complex system characterized by a certain structure. Thirdly, the obtained lexical units have been classified into polysemantic and monosemantic ones. Finally, the analysis of dictionary definitions and their interpretation have been made.

At present a system - oriented approach is the basic one in lexis analysis based on the principle that language forms a system of a definite structure. Words constituting it are not isolated but placed hierarchically in the semantic space of the lexis under study. Furthermore, the main aim of semantic analysis is to represent the meanings of the adjectives in the language system as well as to show how they are interrelated within the lexico-semantic group in question.

Results and discussions. Scholars are primarily interested in the classification of emotional vocabulary, its structure as well as problems of national cultural specificity and its verbal and nonverbal manifestations. There are two ways of verbalizing emotions: verbal (by means of language means) and nonverbal (tone of voice, prosody, mimics, gestures, facial expressions etc.). Emotion as a psychic phenomenon reflects the emotional attitude to reality in human consciousness. Emotional evaluation is imprinted in the semantics of the language means used for verbalization.

English, like any other language, is intimately bound up with the history of its speakers, bearing the imprint of what is specific to their national life and culture in the words. It is a unique entity that has its own laws and regularities, reflected in the tendencies of its existence and the dynamics of its functioning. From the lexical point 
of view and taking into account the unity of form and content, English is considered to be quite an independent, individual entity distinguished from all the other units of the same range. Thus, it can be singled out, identified, described and explained in terms of its form and content. The property of being happy makes up a significant for the British paradigm which is closely connected with their worldview, lifestyle and everyday activities. Moreover, it influences the ways they perceive the objective reality.

The adjective happy in the Longman Dictionary of English Language and Culture is defined as: 1a. feeling or showing pleasure and contentment; b. causing pleasure and contentment; 2. (about, with) feeling that something is right or good; satisfied; 3. (of events) fortunate; 4. (of behaviour, thoughts, etc.) suitable; 5. willing; glad; not finding it difficult(to); 6. (used in wishes about events or occasions) full of pleasure and success [6, p.597]. The compilers of Longman Dictionary of Contemporary English by the adjective happy mean: 1. having feelings of pleasure, for example because something good has happened to you; 2. a happy time, place, occasion etc is one that makes you feel happy; 3. satisfied or not worried; 4. be happy to do smth to be willing to do something, especially to help someone; 5. Happy Birthday/Christmas/Anniversary etc used when greeting someone on their birthday, at Christmas etc; 6 . the happy event the time when a baby is born or when two people get married; 7. a happy medium a way of doing something that is somewhere between two possible choices and that satisfies everyone; 8 . happy as a lark very happy; 9 . not a happy bunny $\mathrm{BrE} /$ not a happy camper AmE humorous someone who is not pleased about a situation; 10. formal suitable [5, p.648]. The semantics of the adjective happy reveals certain characteristics typical of emotions such as ways and degrees of expression (feelings of pleasure), character of evaluation and motivation (satisfied or not worried), their functions (that makes you feel happy).

Moreover, happy makes up a synonymic row consisting of both polysemantic and monosemantic lexical units. Each of the latter ones, besides its common to other words semantics, possesses individual, specific characteristics. English vocabulary contains 38 adjectives to express the property of being happy: happy, cheerful, content, contented, delighted, ecstatic, elated, glad, joyful, joyous, jubilant, merry, overjoyed, pleasant, pleased, thrilled, exultant, blissful, gay, jolly, mirthful, perky, sunny, intoxicated, excited, fulfilled, golden, cheery, jovial, buoyant, radiant, beatific, exuberant, exhilarated, euphoric, rapturous, chirpy, relieved.

19 monosemantic adjectives denoting the property under study are in the focus of attention in the present paper. They form a definite group of lexical units: contented, content, delighted, elated, joyful, joyous, jubilant, overjoyed, thrilled, exultant, perky, fulfilled, cheery, jovial, exhilarated, euphoric, rapturous, chirpy and relieved. On the whole, they denote the inner peculiarities of psychic or physical state, its outer expression through motives, actions or behaviour. They also describe emotional states that are aimed at full or partial satisfaction of the urgent needs of 
the individual that play an important role in his/her life, motivating a person to achieve different goals in various life situations, activities, etc.

The obtained language material has been analyzed, taking into account the words' semantic characteristics. Much attention has been paid to revealing monosemantic words' common and specific features. The former unite them semantically, whereas the latter separate them, and, at the same time, highlight their own specificity. The adjectives within this group characterize the state of being happy and satisfied because your life is good (contented), very pleased and happy (delighted, overjoyed), extremely happy and excited, especially because you have been successful (elated), very happy, or likely to make people very happy (joyful, joyous), extremely happy and pleased because you have been successful, or full of people who feel this way (jubilant), happy or making you feel happy (cheery), happy and active (chirpy), feeling very happy and excited (euphoric), feeling extremely happy, excited, and full of energy (exhilarated), very happy or proud, especially because you have succeeded in doing something (exultant), happy and satisfied because your life is interesting and you are doing useful or important things (fulfilled), friendly and happy (jovial), confident, happy, and active (perky), expressing great happiness or admiration - used especially in news reports (rapturous), feeling happy because you are no longer worried about something (relieved) and very excited, happy, and pleased (thrilled).

Specific feature of monosemantic lexical units lies in the presence of their meanings' intensifiers (very, extremely) combined with their own peculiar connotations (because your life is good, because you have been successful, full of energy, especially because you have succeeded in doing something, because your life is interesting and you are doing useful or important things, used especially in news reports, because you are no longer worried about something). This speaks in favour of the fact that being happy presupposes feelings of great satisfaction, excitement, pleasure, success, confidence, friendliness etc. To sum up, the impressions that accompany the feelings of happiness have positive character and prepare a person to cope with all possible unexpected happenings and their consequences as well as encourage a person to do useful or important things and be full of energy and action. Within the group of monosemantic adjectives one can find their subtle differences of usage. For example, being contented depends more on having a comfortable life whereas being content can depend more on your attitude to your life: you can have to be content or learn to be content. People or animals can be contented but only people can be content. Feeling pleased can suggest that you have judged somebody/something and approve of them; it can also mean that something has happened that is particularly good for you. Feeling glad can be more about feeling grateful for something, either for yourself or somebody else. Happy can mean glad or pleased or satisfied. Overjoyed or thrilled may express a stronger feeling than delighted, but the latter can be made stronger in combinations with absolutely/more than/only too. Overjoyed and thrilled can be made negative and ironic with not exactly/less than. 
The linguocultural approach to the study of the words' lexical semantics has shown that regardless of their common meaning of being happy, the adjectives under research specify this notion in their own way by describing the intensity of feelings, motives, consequences and certain personal qualities needed to be happy. For the British a happy person is active, full of energy, excited, confident, friendly, pleased, not worried, satisfied with his/her life, proud of his/her achievements, and hopeful because life is good, he/she is doing useful or important things as well as he/she succeeded in doing something. Being happy in English is primarily characterized by the emotions of pleasure, joy, excitement, satisfaction, and refers to highly positive feelings and properties. Self-assertive, self-assured, self-confident, self-conscious, self-controlled, self-disciplined, self-made, self-possessed, self-supporting, selfwilled belong to the human qualities which help become happy and enjoy life.

Conclusions. Happiness is an intelectual evaluation, favourable life balance, bliss and peacefulness, activity and personal refinement. As the English interpret the property of being happy as a positive emotional state, its lingual embodiment presupposes the satisfaction of their desires and needs, achieving their goals, etc. Happiness, as any other basic human emotion, has its unique characteristics, which are verbalized by lexical means of the English language.

Monosemantic adjectives denoting the property of being happy in the English language world picture form a complex structure, whose elements serve as the basic means of verbalizing emotions and emotional states. The semantic relations between the units under research prove the existence of inseparable links between the words used to express and describe emotions. In English lexis a group of monosemantic adjectives occupies a significant place in its semantic space. The latter also defines the role of each word within the system as well as different semantic relations existing between them. All the lexical units under study are united into semantic microsystems (e.g. "pleased", "satisfied", "lucky", "excited", "friendly", etc.) on the basis of their common meanings and can form synonymic pairs and rows. Their distinctive characteristics specify each of the words' peculiar semantics. Taken together, these features reveal the semantic specificity of our language material, i.e. its ability to belong to different semantically related as well as unrelated lexicosemantic groups within the system of English. Besides, used in combinations with other words and in various contexts, they help reveal even subtle shades of the words' semantics. Furthermore, the relations which monosemantic adjectives establish with other lexical units within the system of language, make it possible to highlight the whole complex system and structural organization of the English vocabulary.

The perspective for the further study is an in-depth lexico-semantic analysis of polysemantic adjectives denoting the property of being happy in modern English. Emotivity itself generates scientific interest and therefore requires further linguistic research dealing with both linguocultural and semantic peculiarities of other groups of lexis denoting the feeling of happiness in related as well as unrelated language systems. 


\section{REFERENCES}

1. Селіванова О. С. Основи теорії мовної комунікації. Черкаси: Видавництво Чабаненко Ю. А., 2011. 350 с.

2. Шаховский В. И. Категоризация эмоций в лексико-семантической системе языка. М.: ЛКИ, 2008. 206 с.

3. Fabian M. Lexical Semantics: New Approach to its Study. Journal of Interdisciplinary Philology.2013. Issue 1-2. P. 5-12.

4. Fabian M.P. Structural Approach to the Study of Meaning (on the material of adjectives in modern Ukrainian). Philosophy of Language and New Trends in Translation Studies and Linguistics: Collective Monograph. Lviv-Torun: Liha-Press, 2019. Chapter 3. P. 34-51.

\section{LIST OF LEXICOGRAPHICAL SOURCES}

5. Longman Dictionary of Contemporary English/ed. D. Summers. $3^{\text {rd }}$ edition. Essex: Longman Group UK Limited, 1995. 1668 p.

6. Longman Dictionary of English Language and Culture/ed. D. Summers. Essex: Longman Group UK Limited, 1992. 1528 p.

7. Oxford Learner's Thesaurus. A Dictionary of Synonyms / ed. D.Lea. Oxford: Oxford University Press, 2008. 1008 p. 